\title{
Trust as a Social Capital for Entrepreneurship to Create Innovation
}

\author{
Andrean Kisima Oei and Aluisius Hery Pratono \\ Department of Business and Economics, Universitas Surabaya, Surabaya \\ e-mail: 5120143.andrean@gmail.com
}

\begin{abstract}
One indicator of the success of an entrepreneur can be measured by the innovation he created. It is essential that an entrepreneur has the ability to interact and work together in groups so that innovation can be created. Trust is a social capital that makes internal cooperation work well. Competitive aggressiveness is one of the dimensions of entrepreneurial orientation that is still contractual in its impact on innovation. This study wants to find out the relationship between trust in competitive aggressiveness and innovation and the effect of competitive aggressiveness on innovation. Data collection collected using a questionnaire consisting of two parts, the first in the form of open questions to find out problems or difficulties experienced by students and in the second part in the form of questions with a Likert scale. The data took from students who took entrepreneurship courses at UBAYA university. The data collected amounted to 100 and then processed by PLS-SEM analysis using $\alpha=5 \%$. This study found that trust is a critical factor for innovation creation and positively influences to bring about competitive aggressiveness. Trusts make the process of working together and sharing information in groups work well. Other findings from this study also show that competitive aggressiveness has a positive impact on innovation.
\end{abstract}

Keywords-Trust,Social Capital, Competitive Aggressiveness, Innovation.

\section{INTRODUCTION}

S UCCESSFUL of an entrepreneurship education program is determined by the ability to innovate in a business environment with high uncertainty. Technological developments, demographics, and lifestyle changes require the ability to adapt to developing innovation. Innovations produced by entrepreneurs will create new jobs and create new markets in the economic. At present, studies on entrepreneurship indicate that a business innovation model is a key to survival and growth [1] [2].

Process of developing innovation, the creation of collaboration within the internal organization is crucial in optimizing the capabilities of each member of the organization, including internal knowledge. Social interaction between individuals in organizations allows for a coordinating mechanism that is able to solve internal obstacles in the organization. When an innovation arises from the combination and recombination of knowledge that is facilitated by interpersonal information and shared advice some previous research identified a research gap about the innovation model, including factors that determine the success of innovation. The development of entrepreneurial behavior for young people is inseparable from the efforts of educational institutions in pushing ideas and ideas into a business. Some study programs are directed at developing information technology-based innovations in specific sectors, such as tourism [3]. The experience of students working together in various entrepreneurship programs proves that there is a positive impact on the realization of new ventures [4]. However, perceptions of business risk largely determine student interest in turning innovation into a business [5].

Several studies have shown that trust is a crucial factor in groups to create innovation because trust in groups will make the group run better and work together because of open communication as well as a positive view of fellow group members so that it is easy to exchange information and knowledge [6] [7]. On the other hand, the existence of an aggressive attitude is believed to be the key to success in an entrepreneurial context, even though it can harm trust. Lumpkin and Dess (1996) propose an element of an aggressive attitude that must be possessed by an entrepreneur to be able to create a competitive advantage in a business called the entrepreneur orientation (EO) [8].

Contradictory from other studies that do not agree with an aggressive attitude in competition, a decision taken impulsively without an adequate strategy will not succeed and does not have a positive impact on business performance [9]. For some types of companies, people consider that an aggressive attitude is a reckless act and spends money to deal directly with competitors, and of course, this will have a negative impact on the company [10]. Research by Lassen et al. (2006) also found that aggressive attitudes in competition do not have an impact on innovation, especially when we talk about radical innovation because an aggressive attitude tends to focus more on what competitors are doing compared to seeing market trends that exist in the community [9][11] .

The results of this study indicate that competitive aggressiveness has a positive influence on company performance and innovation [12] [13][14]. It is one of the reasons that attract attention to re-examine the dimensions of competitive aggressiveness in the process of creating innovation because often people consider aggressive attitude in sailing is a negative attitude because it is impulsive in making decisions. Research by Nadkarni et al. (2016) says that an aggressive attitude in the competition is more suitable for businesses with a highly competitive environment and also their environment that changes rapidly [15]. 
The $1^{\text {st }}$ International Conference on Business and Engineering Management (IConBEM 2020)

February $1^{\text {st }} 2020$, Institut Teknologi Sepuluh Nopember, Surabaya, Indonesia

Table 1.

Problems Summary Summarize from open question quetionaire.

\begin{tabular}{lc}
\hline \hline \multicolumn{1}{c}{ Difficulties about group } & Difficulties about product \\
\hline $\begin{array}{l}\text { 1. Different orientation about } \\
\text { product }\end{array}$ & 1.there is no supplier \\
$\begin{array}{l}\text { 2. Doubting the ability of } \\
\text { colleagues }\end{array}$ & $\begin{array}{l}\text { 2. cant predict and arrange the } \\
\text { market }\end{array}$ \\
$\begin{array}{l}\text { 3. Hard to communicate and } \\
\text { incoordination }\end{array}$ & 3. there is no selling capabili \\
$\begin{array}{l}\text { 4. Passive member } \\
\begin{array}{l}\text { 5. Reluctant to join a group } \\
\text { with students from different } \\
\text { majors }\end{array}\end{array}$ \\
\hline
\end{tabular}

Table 2.

Outer loading. Processed with SmartPLS 3.0.

\begin{tabular}{ccc}
\hline \hline Latent Variable & Indikator & Loading Factor \\
\hline & TR 1 & 0.790 \\
TR 2 & 0.812 \\
Trust & TR 3 & 0.831 \\
& TR 4 & 0.830 \\
& TR 5 & 0.892 \\
& TR 6 & 0.853 \\
TR 7 & 0.775 \\
Aggressiveness & TR 8 & 0.739 \\
& TR 9 & 0.779 \\
Innovation & AGR 1 & 0.888 \\
& AGR 2 & 0.894 \\
& INV 1 & 0.904 \\
& INV 2 & 0.902 \\
INV 3 & 0.707 \\
\hline \hline
\end{tabular}

\section{A. Previous study}

Found that trust is influenced by three factors, namely perceived ability, integrity, and benevolence. Innovation process which is divided into two stages, stages First there is the idea generation (IG), which is the process of discussing together with the team to look for ideas or innovations to be made, then the implementation or realization (IR) stage, which is the team working to realize the ideas discussed earlier into something applicable and useful. The study was conducted on two companies in Australia, company A had 58 employees, and company B was a company with an R\&D division that had 13 offices with a total of 550 employees.

The results of this study indicate the importance of the trust factor based on the individual's perception of his colleagues regarding perceived ability, integrity, and benevolence so that the process of sharing information or transferring knowledge and cooperation can work in project teams to innovate. In this study, perceived of ability has an understanding of one's views on the ability or competence of his colleague, benevolence is a view of how to behave, ego, caring, kindness or sincerity of colleagues, integrity speaks to view the commitment to work and on promises that are he said and how his colleagues adopted the values of life. The results showed that in the early stages of team formation, the benevolence factor was the critical factor opening and then supported by the perceived ability. If someone has high
Table 3.

Quality model criteria. Processed with SmartPLS 3.0.

\begin{tabular}{cccc}
\hline \hline Latent Variabel & CR & CA & AVE \\
\hline Trust & 0.935 & 0.941 & 0.794 \\
CompetitiveAggressiveness & 0.741 & 0.741 & 0.711 \\
Innovation & 0.800 & 0.866 & 0.660 \\
\hline \hline
\end{tabular}

Table 4.

Multicollinearity test. Processed with SmartPLS 3.0.

\begin{tabular}{cccc}
\hline \hline Indikator & VIF & Indikator & VIF \\
\hline TR1 & 2.374 & TR8 & 2.734 \\
TR2 & 2.665 & TR9 & 2.532 \\
TR3 & 2.576 & AGR1 & 1.529 \\
TR4 & 2.494 & AGR2 & 1.529 \\
TR5 & 3.253 & INV1 & 2.175 \\
TR6 & 2.71 & INV2 & 2.062 \\
TR7 & 2.852 & INV3 & 1.429 \\
\hline \hline
\end{tabular}

Table 5.

Bootstrapping analysis. Processed with SmartPLS 3.0.

\begin{tabular}{|c|c|c|c|c|c|}
\hline & $\begin{array}{c}\text { Orgina } \\
\text { l } \\
\text { Sampl } \\
\mathrm{e}(\mathrm{O})\end{array}$ & $\begin{array}{l}\text { Sample } \\
\text { Mean } \\
\text { (M) }\end{array}$ & $\begin{array}{l}\text { Standard } \\
\text { Deviation } \\
\text { (STDEV) }\end{array}$ & $\begin{array}{c} \\
\text { Statistic } \\
(\mid \mathrm{O} / \mathrm{STD} \\
\mathrm{EV} \mid) \\
\end{array}$ & $\begin{array}{c}\mathrm{P} \\
\text { Values }\end{array}$ \\
\hline $\begin{array}{l}\text { Trust -> } \\
\text { Innovation } \\
\text { Trust -> }\end{array}$ & 0.291 & 0.261 & 0.065 & 1.775 & 0.076 \\
\hline $\begin{array}{l}\text { Competitive } \\
\text { Aggresiveness } \\
\text { Competitive }\end{array}$ & 0.405 & 0.407 & 0.072 & 5.897 & 0 \\
\hline $\begin{array}{l}\text { Aggresiveness - } \\
\text { > Innovation }\end{array}$ & 0.257 & 0.392 & 0.063 & 6.281 & 0 \\
\hline
\end{tabular}

skills but low benevolence, it will be difficult to communicate at the beginning due to misunderstanding or negative perceptions first, and this will make people not even want to form a team together from the start. Even if the benevolence between peers is high, the process of knowledge transfer can go on and make the ability among peer groups increase. Integrity is no less important than the previous two factors, people who are considered to have low integrity will be avoided in groups because they are afraid that they will steal ideas together for personal gain or the ideas discussed have never been realized. The implication of this research is to suggest that companies focus on training that builds interpersonal skills such as caring for groups or aiming at increasing integrity, if they focus on these soft skills, groups will work well together and automatically each person's competence will also increase.

Research by Pratono (2018) entitled "From social network to firm Performance" and also "Network structure and open innovation: the role of trust in product development" shows that trust has a vital role in company performance and also product development in an irregular way [16]. To be able to develop products and also improve performance, it requires a network structure. Trust is a must when companies want to form a network structure. A network without trust will make the company more fragile, and the failure rate will be even greater. A network structure that has trust will be more willing to take risks, and the network will also have marketing capability, selling capability, and also pricing capability.Lassen et al. (2006) carried out case studies from several large companies that 
The $1^{\text {st }}$ International Conference on Business and Engineering Management (IConBEM 2020)

February $1^{\text {st }} 2020$, Institut Teknologi Sepuluh Nopember, Surabaya, Indonesia

had entirely innovations or what we call radical innovations[11]. The results showed that EO dimensions such as autonomy, risk-taker behavior, proactive have a positive impact on radical innovation, but the competitive aggressiveness dimension alone has no positive effect. Radical innovation talks about creating a new product and market that does not yet have competitors there, while competitive aggressiveness is an attitude that focuses on what is done by competitors [11]. Nadkarni et al. (2016) researched shown a different result, data analysis used from 258 companies from 23 types of industries and the data used were obtained from 1995 to 2000, showing competitive aggressiveness has a positive effect on performance and innovation, the faster the environment change the stronger the influence [15]. Researched by Liu and Fang (2016) also shows that competitive aggressiveness has a positive effect on innovation by mediating risk-taker variables as mediators [13].

\section{B. Hypothesis}

\section{1) Exploring trust impact on innovation}

As explained earlier, the process of creating innovation is full of risks and uncertainties and depends on teamwork to share information and knowledge between members. Trusts reduce the level of uncertainty and allow members between one team to share information. The more dynamic and complex an organization and business will be, the high trust is needed, trust in the organization is an essential key in the innovation process [7]. If a group does not have minimal trust at the medium level, then the process of sharing information, transferring knowledge, and innovation will not occur [17]. H1: Trust directly influences innovation.

2) Exploring Trust Influencing Competitive Aggressiveness

Lumpkin and Dess (1996) explain that competitive aggressiveness is the attitude of a company or group to make bold decisions in order to win market share and outperform its competitors by responding directly to competitors. A high-risk decision to outperform its competitors in the market clear requires analysis and teamwork as well as information shared in the team. The role of trust here is to enhance interaction and cooperation processes in groups. It will make the group bolder to take an aggressive attitude towards competition. H2: Trust is positively related to competitive aggressiveness.

3) Exploring Impact of Competitive Aggressiveness on Innovation

Based on the model formulated by Lumpkin and Dess (1996), competitive aggressiveness and proactiveness are two things that will measure entrepreneurs on company performance and product development. Several studies have shown that in evaluating a variable performance, proactiveness has a more positive effect on performance than aggressiveness [9]. Proactiveness focuses more on market trends so that it will be right to create new demands in the market, and this causes proactiveness to have a more positive effect on innovation than with competitive aggressiveness. Different from proactiveness, competitive aggressiveness is more focused on competitors, but product development or product or service modification that is developed based on competitors can be a product of unity. The findings by some researchers also support that competitive aggressiveness has a positive effect on innovation creation [13][9][12]. In some conditions sometimes a decision needs to be taken with a short time, the company's ability to take aggressive steps can make them make decisions quickly and also be able to respond to changes in the environment and threats from competitors, this also will contribute to the creation of innovation [13]. Then we can assume that competitive aggressiveness has a positive impact on innovation because the effort to defeat competitors through product modification can be said as a product development effort. H3: Competitive aggressiveness positively influences innovation.

\section{II.METHOD}

This is a Quantitative Research. The data source in this study uses primary data obtained directly from students who took entrepreneurship courses using a questionnaire that was distributed directly randomly while they were exhibiting. The questionnaire distributed consisted of two parts, the first was in the form of open questions to find out the problems and difficulties of students in this course and also questions with Likert scale to measure the variables of trust, competitive aggressiveness and innovation.

The sample that will be used is from UBAYA students who are taking entrepreneurship courses. The groups are combined from two different majors, first is engineering faculty and the other one form business and economics faculty. More than 600 students are taking this course, and they will be formed in groups of 12-19 people each. The whole group formed was 18 groups. Data collected amounted to 100 questionnaires.

\section{A. Operational Defenition}

The questionnaire used was adapted from several previous studies. Trust is Perception of the quality of interpersonal relationships of individuals in the group [18]; [19], competitive aggressiveness is the attitude of individuals in facing aggressive competition to outperform competitors [20], innovation is the level of individual ability to be able to think innovatively [20].

Open questions asked in the questionnaire are as follows: (1)What difficulties do groups face in this entrepreneurship course?; (2)Are members interested in continuing the existing business in this course? Tell the reason? Hypothesis testing is done by analysis using structural equation modeling. The program used is Smart-PLS 3.0. First of all, the feasibility of measuring tools will be tested based on validity and reliability tests. The minimum outer loading value of each item is 0.7 . Cronbach alpha and composite reliability to see the reliability of measuring instruments, the minimum value of Cronbach Alpha and composite reliability is 0.6 . The AVE standard must be more than 0.5 to meet the convergent validity requirements. The classic assumption test is done to prove that the measuring instrument used does not have a multicollinearity problem by looking at the VIF value. 


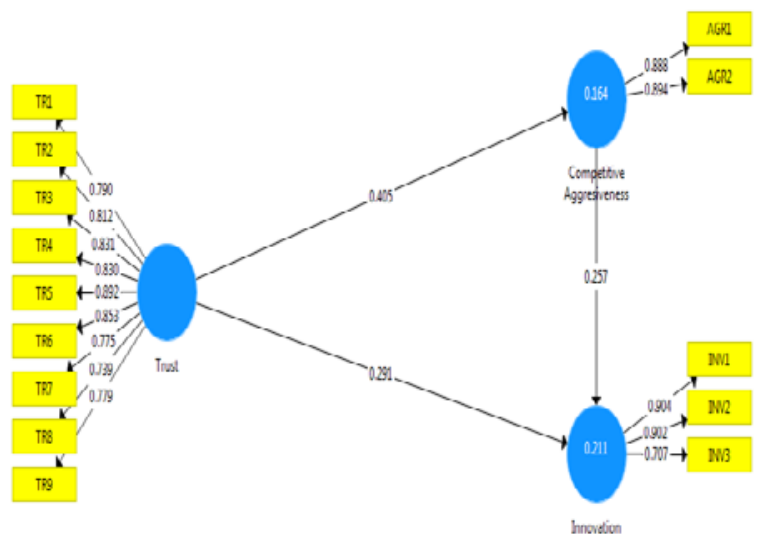

Figure 1. Path analysis. It is processed with SmartPLS 3.0.

\section{RESULT AND DISCUSSION}

Based on table 1 we can know that the biggest problems $76 \%$ is the result of the lack of trust in the group that causes students to experience difficulties related to groups such as hard to work together, difficult to unite the mind, and incoordination.there is no students also felt the products they offered were less innovative and had a small market opportunity, so they all answered they did not want to continue the products they made in this course as a business to be developed, although some of them chose not to continue because they already had own business or other planning. Students also felt the products they offered were less innovative and had a small market opportunity, so they all answered they did not want to continue the products they made in this course as a business to be developed, although some of them chose not to continue because they already had own business or other planning.

There are several other factors also related to the product, such as difficulties in finding ideas, difficulty in finding funds, difficulty in finding suppliers, difficulty in marketing products.The results of the testing of the feasibility of a measuring instrument with a sample size of 100 people showed results like the following table on 2 .

Based on the outer loading value, all items used to retrieve data trust, competitive aggressiveness, and innovation meet the standards because they have a value of more than 0.7 on table 3 . Table 2 shows the reliability measures. CR and CA show how the variables have consistency. The measures come from values of CR and CA, which are greater than 0.7. According to table 4, the values of AVE show that all variables have a value greater than 0.5 , which indicates that all variables are meet the validity requirement. This test shows that variances of the constructs are greater than the number of variances due to measurement error, which implies that the convergent validity of the observed variables is accepted After all, items meet the criteria, and it can be used in the next step. Bootstrapping value analysis results and path analysis will represent the quality of the inner model and answer the research hypotheses on figure 1. Path coefficients show that trust directly influences innovation. We have also known based on previous studies that trust is a factor that must arise in groups so that the process of innovation creation can take place; [6][7][21], in this study especially proving that Trust influences other variables such as competitive aggressiveness that play an important role in creating innovation.

The process for creating innovation is at a stage where everyone in the group will try to find ideas and also try to realize or implement the idea, and therefore there needs to be a good relationship between members so that the process of communication, sharing knowledge and information can occur. This reason makes trust so important in the process of creating innovation. Trust is basically social capital such as interpersonal skills that make people able to interact and work well with others [6] if we refer to the capability theory, so we can utilize resources self-power and external resources such as the superiority of others to create a series of cooperation so that competitive advantage appears, therefore trust is a key factor for the group to run well and be able to show the expected results.

The data on table 1 shows that students experience problems in working together in groups regarding incoordination, difficulty in uniting minds, poor expectations of teammates. These things make it difficult for them to be able to create or develop innovative products because if a group does not have a sufficient level of trust, it will be difficult to work together [17].

The dimensions of trust, which are divided into perceived ability, integrity, and benevolence. If we try to look back on the environmental conditions of the responses given by respondents and are connected with research, it can be said that each group has a lack of overall dimensions of trust that makes them experience obstacles to be able to work together, some of them from the beginning felt reluctant to to join the group with the faculty others, show that in fact, they do not know each other well, so there are many negative perceptions and ignorance of the work abilities of their colleagues. This statement is supported by some answers from students who feel their partners are passive and do not care about the group, and there are also those who make reports carelessly. Another problem that arises also is the ability to find suppliers, find markets, and market products. Trust in groups is not just helping the innovation process, Pratono (2018) shows that the trust in the group will increase the group's ability to build networking and also the ability to sell their products will have a positive impact on their eventual performance on table 5 [7].

$\mathrm{H} 2$ is accepted, based on the value of the path coefficients and $\mathrm{p}$ values. This shows that trust has a positive effect on competitive aggressiveness as we know that competitive aggressiveness is an attitude to take courageous actions to be able to excel in business and defeat competitors with decisions whose results are uncertain and also high in risk [8]. Trust in the group will function as social capital to make the process of transfer of knowledge and information so that it can be used in analysis of decision making will reduce the level of uncertainty from the environment and within the group so that it encourages competitive aggressiveness to emerge in the group due to the belief among group members when making a decision;[7] [21] The group who have trust, 
The $1^{\text {st }}$ International Conference on Business and Engineering Management (IConBEM 2020)

February $1^{\text {st }} 2020$, Institut Teknologi Sepuluh Nopember, Surabaya, Indonesia

they will be more confident in the abilities of their peers and more confident in group decisions so that they will be more willing to take risks and be aggressive. For example, if some people in the group come up with ideas, and everyone in the group believes in them, they will certainly also believe in the ideas that their colleagues convey so that they will be able to work in synergy and are ready to take risks from their decisions because they believe in the opportunities that exist, even failing even if the risk will be shared with other members [16]

Hypothesis 3 is accepted, the result of this study reinforces that competitive aggressiveness is also an important factor to trigger an innovation to emerge, of course, innovation in this study is independent of the type of innovation itself regarding radical innovation or incremental innovation. Aggressiveness often sounds negative because it looks like an impulsive attitude. It is also widely assumed that competitive aggressiveness is a dangerous action and makes the company down its performance [10] but when the environment is more dynamic competitive aggressiveness will actually produce a positive impact. The faster changes that occur in the environment and the stronger competition that occurs business, we also need to make decisions quickly, and an aggressive attitude will make us able to do that [13]. Competitive aggressiveness will enable us to use and allocate our resources quickly and appropriately in the competition and this makes companies able to excel because they are able to move quickly and also continue to improvise their products or services.

\section{CONCLUSION}

This study aims to look at the problems that occur in student groups who take entrepreneurship courses and finally find that the main factor that causes group difficulties is the trust factor. Problems faced by students are difficulties in working together, sharing information, difficulties in establishing networking as a supplier, and their target market. As we discussed in the previous chapter, if trusts in a group can be raised or increased then these problems will be solved more easily, but members in the group do not have trust at a sufficient level so that the process of cooperation does not go well and produce failure in innovation [17].

Based on previous research by Lazányi (2017), Pratono (2018), and the results of this study show the same results that trust does not directly affect innovation. Nevertheless, we must understand that trust is one of the basic foundations of social capital needed as a form of interpersonal skills to be able to establish relationships between individuals so that each individual can use the strength within themselves possessed by each individual in synergy to produce a good performance. Trust not only plays an important role in the process of innovation, but with groups working well together and sharing information, they are also able to build networks so that they can find the right suppliers and determine and sell their products and services to predetermined markets [16].
Supporting the statement above, the results of this study also show that trust influences positively the dimensions of entrepreneurial orientation that are specific to competitive aggressiveness. The dimensions of entrepreneur orientation itself, according to some previous studies and the results of this study show positive results on innovation. The process of innovation is indeed risky and fraught with high uncertainty [21] therefore, it is very clear that if we succeed in innovating we must also be more willing to take risks because it will enlarge opportunities to succeed. Daring to take risks means focusing on opportunities rather than failure.

The results of research on competitive aggressiveness that affect innovation also support the research of [13] as well as [12]. When taking an aggressive attitude, it will also encourage risky decisions, and as discussed previously, it is something that will increase the chances of innovation. Competitive aggressiveness also affects innovation directly regardless of innovation, radical innovation, or incremental innovation. Create innovation, it is necessary to look at market trends and future project needs [22], but by looking at competitors as well as benchmarking and continuing to try to excel from competitors will also open up opportunities for innovation. At present, access to information is very fast and easy, this certainly becomes a change in trends, and the environment becomes more dynamic so that the attitude of making decisions quickly and boldly will have a positive influence [12].

\section{REFERENCES}

[1] P. R. A. Oeij, W. van der Torre, F. Vaas, and S. Dhondt, "Understanding social innovation as an innovation process: applying the innovation journey model,” J. Bus. Res., vol. 101, pp. 243-254, Aug. 2019, doi: 10.1016/j.jbusres.2019.04.028.

[2] M. Geissdoerfer, D. Vladimirova, and S. Evans, "Sustainable business model innovation: a review,” J. Clean. Prod., vol. 198, pp. 401-416, 2018, doi: 10.1016/j.jclepro.2018.06.240.

[3] V. Ndou, G. Mele, and P. Del Vecchio, "Entrepreneurship education intourism: an investigation among european universities.," J. Hosp. Leis. Sport Tour. Educ., vol. 25, pp. 1-11, 2019, doi: 10.1016/j.jhlste.2018.10.003.

[4] T. Ahmed, V. G. R. Chandran, J. E. Klobas, F. Liñán, and P. Kokkalis, "Entrepreneurship education programmes: how learning, inspiration and resources affect intentions for new venture creation in a developing economy," Int. J. Manag. Educ., vol. 18, no. 1, p. 100327, Mar. 2020, doi: 10.1016/j.ijme.2019.100327.

[5] C. Bandera, R. Collins, and K. Passerini, "Risky business: experiential learning, information and communications technology, and risk-taking attitudes in entrepreneurship education,” Int. J. Manag. Educ., vol. 16, no. 2, pp. 224-238, 2018, doi: 10.1016/j.ijme.2018.02.006.

[6] M. Thompson, Social Capital, Innovation and Economic Growth. J. Behav. Exp. Econ, 2018.

[7] A. Pratono, "Network structure and open innovation: the role of trust in product development," Int. J. Bus. Innov. Res, vol. 15, no. 44, 2018, doi: 10.1504/IJBIR.2018.10009021.

[8] G. T. Lumpkin and G. G. Dess, "Clarifying the entrepreneurial orientation construct and linking it to performance," Acad. Manag. Rev., vol. 21, no. 1, pp. 135-172, 1996, doi 10.5465/AMR.1996.9602161568.

[9] L. Kozubíková and A. Zoubková, "Entrepreneur's attitude towards innovativeness and competitive aggressiveness: the case study of czech micro-enterprises,” J. Int. Stud., vol. 9, no. 1, pp. 192-204, 2016, doi: 10.14254/2071-8330.2016/9-1/14.

[10] V. E. Jancenelle, S. Storrud-Barnes, and R. R. G. Javalgi, “Corporate entrepreneurship and market performance: a content analysis of earnings conference calls,” Manag. Res. Rev, vol. 40, pp. 352-367, 
The $1^{\text {st }}$ International Conference on Business and Engineering Management (IConBEM 2020)

February $1^{\text {st }} 2020$, Institut Teknologi Sepuluh Nopember, Surabaya, Indonesia

2017, doi: 10.1108/MRR-01-2016-0019.

[11] A. H. Lassen, F. Gertsen, and J. O. Riis, "The nexus of corporate entrepreneurship and radical innovation,” Creat. Innov. Manag., vol. 15, no. 4, pp. 359-372, 2006, doi: 10.1111/j.1467-8691.2006.00406.x.

[12] S. Nadkarni, T. Chen, and J. Chen, "The clock is ticking ! executive temporal depth , industry velocity and competitive aggressiveness the clock is ticking! executive temporal depth , industry velocity, and competitive aggressiveness,” vol. 37, no. 6, pp. 1132--1153, 2016, doi: doi: 10.1002/smj.02376.

[13] C. H. S. Liu and Y. P. Fang, "Night markets: entrepreneurship and achieving competitive advantage,” Int. J. Contemp. Hosp. Manag., vol. 28, no. 11, pp. 2374-2398, Nov. 2016, doi: 10.1108/IJCHM-032015-0114.

[14] A. Ključnikov, J. Belás, and L. Smrčka, "The role of risk-taking and competitive aggressiveness in management of smes," Polish J. Manag. Stud., vol. 14, no. 1, pp. 129-139, 2016, doi: 10.17512/pjms.2016.14.1.12.

[15] S. Nadkarni, T. Chen, and J. Chen, "The clock is ticking ! executive temporal depth, industry velocity and competitive aggressiveness the clock is ticking! executive temporal depth , industry velocity, and competitive aggressiveness,” Strateg. Manag. J., vol. 37, no. 6, pp. 1132-1153, Jun. 2016, doi: 10.1002/smj.2376.

[16] A. H. Pratono, "From social network to firm performance: The mediating effect of trust, selling capability and pricing capability," Manag. Res. Rev., vol. 41, no. 6, pp. 680-700, 2018, doi:
10.1108/MRR-03-2017-0080.

[17] S. Y. Cheung, Y. Gong, M. Wang, L. (Betty) Zhou, and J. Shi, "When and how does functional diversity influence team innovation? The mediating role of knowledge sharing and the moderation role of affect-based trust in a team," Hum. Relations, vol. 69, no. 7, pp. 1507-1531, Jul. 2016, doi: 10.1177/0018726715615684.

[18] S. C. Chang and M. S. Lee, "A study on relationship among leadership, organizational culture, the operation of learning organization and employees' Job Satisfaction,” Learn. Organ., vol. 14, no. 2, pp. 155-185, Mar. 2007, doi: 10.1108/09696470710727014.

[19] H. Li and A. O'Connor, "The entrepreneurial influence on winery market performance - a mediation perspective,” Int. J. Wine Bus. Res., vol. 29, no. 2, pp. 210-232, 2017, doi: 10.1108/IJWBR-112016-0037.

[20] G. T. Lumpkin, C. C. Cogliser, and D. R. Schneider, "Understanding and measuring autonomy: an entrepreneurial orientation perspective.' entrepreneurship theory and practice,” Seizure, vol. 14, no. 806, pp. 47-70, 2009, doi: 10.1111/j.1540-6520.2008.00280.x.

[21] K. Lazányi, “Innovation - The role of trust,” Serbian J. Manag., vol. 12, no. 2, pp. 331-344, 2017, doi: 10.5937/sjm12-12143.

[22] L. Kozubíková, G. Sopková, V. Krajčík, and L. Tyll, "Differences in innovativeness, proactiveness and competitive aggressiveness in relation to entrepreneurial motives,” J. Int. Stud., vol. 10, no. 4, pp. 207-218, 2017, doi: 10.14254/2071-8330.2017/10-4/16. 